\title{
International Trading Prices Of India's Oilseed Crops: Growth Rates, Elasticities And Foreign Trade Policy
}

\author{
M.B. Dastagiri, Principal Scientist \\ S.M Jainuddin, Junior Research Fellow \\ ICAR-National Academy of Agricultural Research Management, \\ Rajendranagar, Hyderabad, India
}

Doi: 10.19044/esj.2017.v13n31p185 URL:http://dx.doi.org/10.19044/esj.2017.v13n31p185

\begin{abstract}
World prices influence international trade and so economic precision is required. This foreign trade research study examines exports and imports of India's major oilseeds from 1990-91 to 2015-16. The methodology employed is the estimation of CAGR, Instability Index, Export import price elasticities of oilseeds and identification of top export import destinations. The results show that export prices of groundnut, soybean, niger, safflower, sesamum and sunflower were higher than import prices indicating that India has a comparative advantage in these crops. The terms of trade of India's oilseeds were found to have increased for all oilseeds except mustard crop. The exports price growth rate of groundnut, niger, safflower and sunflower were higher than imports. The study found that among oilseeds, mustard $(0.97 \%)$ has high export elasticity and that export imports prices of groundnut, soybean, safflower, sunflower and niger crops were found to be stable. It also found that India's major exports destinations for groundnut, soybean, niger seeds, sesamum, and sunflower are Indonesia, USA, South Korea and Philippines respectively, whereas major imports destinations are Germany, USA, Nigeria and Ukraine for groundnut, soybean, sesamum, and sunflower respectively. The study suggests that multilateral trade relationship with countries having high export imports share would help in smooth trade of oilseeds. These findings have important implications for policy research and R\&D strategies in response and re-orientation of the $\mathrm{R} \& \mathrm{D}$ system to the changing trade scenario to benefit from WTO.
\end{abstract}

Keywords: CAGR, Oilseeds, Price elasticity, Destinations, World Trading prices, India 


\section{Introduction}

The European Union has been the largest importer of peanuts in the world, mainly through the Netherlands and Germany (Chandrashekhar, 2013). EU imports over last 20 years have been around 7,00,000 tonnes per annum (Chandrashekhar, 2013). South-East Asian countries such as Indonesia, Malaysia and the Philippines regularly import groundnut from India (Chandrashekhar, 2013). India has responded well to global market dynamics during last two decades and has retained its position in peanut exports (Chandrashekhar, 2013). Some 10 to 12 years ago, our Indian exports averaged about 1.5 lakh tonnes which has now risen five-fold to nearly eight lakh tonnes (2011-12) displacing Argentina to gain the top spot as world's largest exporter (Chandrashekhar, 2013). In sesame seeds, India is world's largest producer and exporter (Chandrashekhar, 2013).

India is amongst the largest producer and consumer of vegetable oils in the World. Indian vegetable oil economy is the fourth largest in the world next to USA, China and Brazil and contributes about 10 per cent of the world oilseeds production, 6-7\% of the global production of vegetable oil, and nearly 7 percent of protein meal (Vijay Paul Sharma, 2014). This sector also has an important place in the Indian agricultural sector covering an area of about 26.5 million hectares, with total production of over 29 million tonnes in the triennium ending 2011-12 (GOI, 2013). This constitutes about 14.8 per cent of the gross cropped area in the country. The oilseeds accounted for about 9.8 per cent (at 2004-05 prices) of the total value of output from agriculture in TE 2011-12 (GOI, 2013). India's total oilseed production in $2017 / 18$ is forecast to increase seven percent to $38.6 \mathrm{MMT}$, derived from 40 million hectares. Out year oilseed supplies will achieve an all-time high of 40.3 MMT. (USDA, 2017).

Oilseed crops play the second important role in the Indian agricultural economy next to food grains in terms of area and production. Three main oilseeds namely, groundnut, soybean, and rapeseed-mustard accounted for over 88 per cent of total oilseeds output during the TE2011-12 (Vijay Paul Sharma, 2014). The major other oilseeds cultivated in our country are castor seed, sesamum, nigerseed, linseed, safflower and sunflower. The area under total nine oilseed crops registered growth of 4.3 per cent and production registered growth of around 8 per cent per annum (Narayan et al., 2011).

The market economy depends on world price signals to correctly allocate its scarce resources and stabilize domestic market. Economic precision is required on international prices. Sufficient and reliable information is prerequisite for proper decision making be it domestic market or international marketing. World price means a price for a good or services in all countries other than one's own. The impact of world price variability 
on producers and consumers and the effectiveness of price signals in bringing about adjustments in supply and demand depend on the extent to which world market prices are transmitted to domestic markets (David Hallam 2003).

World price means a price for a good or services in all countries other than one's own (Financial dictionary, 2012). World price influences on international trade. Under modern capitalism, major commercial exports and imports of a country conducted in world prices (Encyclopedia, 2010). A country exports goods and services with local price lower than the world price. On other hand, it imports goods and services with higher local prices than the world price (Financial dictionary, 2012). Based on above explanations the exports and imports prices are considered as world trading price. India's tariff policy was observed to be countercyclical in oilseeds, which is a major import item in the overall agri-trade, and whose import duties are observed to be moving negatively with its global prices i.e. duties are reduced when global prices rise and increased when global prices fall (Shweta and Gulati, 2017).

Some of the review of literature cited related to exports imports growth, price signals and instability of agricultural commodities. Glezakos (1973) showed that a priori argument that export instability is generally larger in the LDCs than in the DCs. Nurkse (1958) and Caine (1958) said export instability is pernicious to economic growth. The export instability could affect foreign exchange earnings and economic growth (Chaudhary and Qaisrani, 2002). Chand and Tewari (1991) reported that the agricultural exports and imports growth was much lower than total merchandise. The export earnings from agricultural products increased because of the rise in unit value (Pal, 1992). Mahadevaiah (2001) showed that the stability in export earnings from total cotton export. Alberto and Stefano (2010) reported that Italy has a relatively low elasticity of substitution main specialization sector (machinery and equipment), while has higher substitution elasticity for traditional goods like textiles, jewelry and leather products. UNCTAD (2009) reported that India's exports to world are very responsive to income changes. A $1 \%$ decline in GDP growth of world will lead to $1.88 \%$ decline in India's growth of exports to world (UNCTAD, 2009). Upender (2007) reported that there is long run as well as short run relationship between export and imports price in India. Singh and Sangla (2012) reported that India has been unable to diversify its exports as well as export destinations.

Economic precision is required on international prices, imports and exports. There are no or limited empirical studies on world trading price signals research of India's oilseeds and agricultural commodities. This study analyses trade signals of imports exports and, prices of major India's oilseed 
crops and identification of their destinations. Finally, the study will suggest multispeed strategies for promotion of trade.

The specific objectives of the study are;

1. To analyze world trading prices of India's oilseed commodities.

2. To estimate export and import price growth rates, trends and instability for India's oilseed commodities trade.

3. To analyze export and import price elasticities for Indian major oilseed crops.

4. To suggest strategies and foreign trade policy to boost oilseed commodities.

\section{Methodology}

This is basically a foreign trade research study. The export and import of major oilseeds with other countries from India were selected for groundnut, soybean, niger seeds, safflower, sunflower, mustard and sesamum. The study period is $1990-91$ to 2015-16. India is exporting these commodities to a maximum of 130 countries. For each commodity, the countries will be classified in to the top 10 countries which accounted major share of exports and rest as other countries. Finally, top 3 countries which accounted major share of India's exports for each commodity will be identified. Data on quantity, values, and prices of exports, imports and destinations of agricultural commodities were collected. Data sources are APEDA, DGCIS, NHB, FAO STAT, CMIE Commodities, NABARD, EXIM, ICAR-IIOR, Foreign Trade Year Book, Planning commission reports.

This research will analyze exports and import price growth rates, trends of major oilseeds and their destinations. The research also estimates import export and price elasticity's, exports market and prices signals of India's oilseeds, identify major Market destinations. The compound annual growth rates (CAGR), price elasticity's, instability and trends of exports and import prices analysis were estimated using the following formulae.

\section{Growth rate formulae: (Damodar N. Gujarati and Sangeetha, 2007)}

The compound growth rate (r) will be calculated by fitting Exponential function to the variables of interest viz., exports, prices for the period 1990-91to 2014-15.

$$
\mathrm{Y}_{\mathrm{t}}-\mathrm{Y}_{0}(1+\mathrm{r})^{\mathrm{t}} \text {---------1 }
$$

Assuming multiplicative error term in the equation1, model may be linearized by logarithmic transformation

$\ln \mathrm{Yt}=\mathrm{A}+\mathrm{Bt}+€$----------2 
Where, A $(=\ln \mathrm{Ao})$ and $\mathrm{B}(=\ln (1+\mathrm{r}))$ are the parameters to be estimated by ordinary least square regression, $t=$ time trend in year, $r=\exp$ (B) -1

Price elasticity of exports formulae:

$\sum \mathrm{P}_{\mathrm{e}}=\%$ change in quantity exports $/ \%$ change in price

The percentage change in quantity exports is $\% \Delta \mathrm{Q}$, and the percentage change in price is $\% \Delta \mathrm{P}$. We calculate $\% \Delta \mathrm{Q}$ as $\Delta \mathrm{Q} / \mathrm{Q}$ ave and We Calculate $\% \Delta \mathrm{P}$ as $\Delta \mathrm{P} / \mathrm{P}$ ave

So we calculate the price elasticity of exports as $(\Delta \mathrm{Q} / \mathrm{Q}$ ave $) /$ $(\Delta \mathrm{P} / \mathrm{P}$ ave $)$

\section{Instability Index Formulae}

Coefficient of variation $=($ Standard Deviation $/$ Mean $) * 100$

\section{Terms of Trade calculation}

$$
\begin{aligned}
& \text { TOT }=\frac{\text { Average Price of Exports }}{\text { Average Price of Imports }}=\text { Px } / \text { Pm } \\
& \uparrow \text { Price } M \text { or } \downarrow \text { Price } X \rightarrow \text { Deterioration ToT } \\
& \downarrow \text { Price } M \text { or } \uparrow \text { Price } X \rightarrow \text { Improvement ToT }
\end{aligned}
$$

\section{Results and discussions}

\section{International Average Export-Import Prices of India's Oilseeds crops}

The average export import prices and TOT of India's oilseeds crops were presented in Table 1. During the period 1990-91 to 2015-16, the export prices of oilseeds for groundnut, soybean, niger seed, safflower, sesamum and sunflower were more than import prices except mustard. It indicates that India has comparative advantage in these oilseeds crops. During the period 2001-02 to 2015-16, in soybean crop observed that import price is more than export price. During the period 1990-91 to 2000-01, the export price of groundnut, niger, mustard, safflower, sesamum and sunflower was found to be more than compared to import price, whereas import price of soybean is more than export price. During the period 1990-91 to 2015-16, the terms of trade of India with other countries found to be improved for all oilseeds crops except mustard crop.

The study found that export prices of oilseeds for groundnut, soybean, niger, safflower, sesamum and sunflower were more than import prices except mustard. The terms of trade of India's oilseeds were found to be increased for all oilseeds except mustard crop. 
Table 1. Average Export-Import Price of Oilseed crops (1990-2016)

\begin{tabular}{|c|c|c|c|c|c|c|c|}
\hline \multirow[b]{2}{*}{ Crops } & \multirow[b]{2}{*}{ Variables } & \multicolumn{3}{|c|}{ Average Export Import price US $\$ / \mathrm{Kg}$} & \multicolumn{3}{|c|}{ Terms of Trade } \\
\hline & & $1990-91$ to $2000-01$ & $2001-02$ to $2015-16$ & $1990-91$ to $2015-16$ & $\begin{array}{c}1990- \\
91 \text { to } \\
2000- \\
01\end{array}$ & $\begin{array}{c}2001- \\
02 \text { to } \\
2015- \\
16\end{array}$ & $\begin{array}{c}1990- \\
91 \text { to } \\
2015- \\
16\end{array}$ \\
\hline \multirow{2}{*}{ Groundnut } & Export & 0.55 & 0.90 & 0.75 & \multirow{2}{*}{3.93} & \multirow{2}{*}{1.34} & \multirow{2}{*}{1.92} \\
\hline & Import & 0.14 & 0.67 & 0.39 & & & \\
\hline \multirow{2}{*}{ Soybean } & Export & 0.19 & 0.54 & 0.40 & \multirow{2}{*}{2.11} & \multirow{2}{*}{0.90} & \multirow{2}{*}{1.21} \\
\hline & Import & 0.09 & 0.60 & 0.33 & & & \\
\hline \multirow{2}{*}{ Niger seeds } & Export & 0.62 & 0.78 & 0.71 & \multirow{2}{*}{0.00} & \multirow{2}{*}{0.00} & \multirow{2}{*}{1.92} \\
\hline & Import & 0.00 & 0.00 & 0.37 & & & \\
\hline \multirow{2}{*}{ Mustard } & Export & 0.49 & 0.59 & 0.54 & \multirow{2}{*}{2.13} & \multirow{2}{*}{0.69} & \multirow{2}{*}{0.98} \\
\hline & Import & 0.23 & 0.85 & 0.55 & & & \\
\hline \multirow{2}{*}{ Safflower } & Export & 0.41 & 0.33 & 0.36 & \multirow{2}{*}{0.00} & \multirow{2}{*}{0.00} & \multirow{2}{*}{6.00} \\
\hline & Import & 0.00 & 0.00 & 0.06 & & & \\
\hline \multirow{2}{*}{ Sesamum } & Export & 0.73 & 1.29 & 1.05 & \multirow{2}{*}{2.52} & \multirow{2}{*}{1.25} & \multirow{2}{*}{1.48} \\
\hline & Import & 0.29 & 1.03 & 0.71 & & & \\
\hline \multirow[t]{2}{*}{ Sunflower } & Export & 0.62 & 0.96 & 0.82 & \multirow{2}{*}{2.21} & \multirow{2}{*}{1.22} & \multirow{2}{*}{1.44} \\
\hline & Import & 0.28 & 0.79 & 0.57 & & & \\
\hline
\end{tabular}

Source: CMIE Commodities, Accessed on $3^{\text {rd }}$ June 2017

\section{Export, Import Prices and Quantity Growth rates \& Instability of India's Major Oilseed crops}

The annual compound growth rates and coefficient of variation of export import quantity and prices of India's major oilseeds were presented in Table 2. During 1990-91 to 2015-16, both export and imports price growth rates of all oilseeds were found to be positive. The export price growth rate of groundnut, niger, safflower and sunflower were more than imports, while reverse trend was observed in soybean, mustard and sesamum crops. It is noticed that among the oilseeds crops, mustard import price $(11.05 \%)$ and sunflower export price $(7.85 \%)$ growth rate was more than compared to other oilseeds export import price. During period 1990-91 to 2015-16, the export import quantity growth of all oilseeds crops were found to be positive except soybean imports $(-1.66 \%)$ quantity. The exports quantity growth rate of groundnut, soybean, mustard was more than the imports quantity growth, while remaining crops has showed a reversed trend quantity growth.

During the period 1990-91 to 2015-16, the variation in exports price and quantity of all oilseeds were found to be more than compared to imports price and quantity except mustard where imports quantity (122.28\%) variation was more than exports quantity. It is observed that the imports price of all oilseed crops were found to be stable except mustard and sesamum imports price more than compared to exports price. The export quantity of all oilseed crops were found to be unstable except exports 
quantity of soybean and mustard, whereas imports quantity of all oilseeds crops were found to be stable except imports quantity of mustard.

The study found that the exports price growth rate of groundnut, niger seeds, safflower, and sunflower were found to be more than imports and conclude that India has comparative advantage in these crops, whereas imports price growth rate of crops; soybean, mustard, and sesamum were found to be more than exports. The results showed that the variation in export prices of oilseeds crops were found to be more than imports prices. The study found that export imports prices of all oilseeds crops were found to be unstable except import price of groundnut, soybean, safflower, sunflower, niger seeds. The imports quantity of all oilseeds except mustard and export quantity of soybean were found to be stable.

Table 2. Growth rate \& Instability of Export Import quantity and Price of Oilseeds (19902016)

\begin{tabular}{|c|c|c|c|c|c|c|c|}
\hline \multirow[b]{2}{*}{ Crops } & \multirow{2}{*}{$\begin{array}{l}\text { Varia } \\
\text { bles }\end{array}$} & \multicolumn{3}{|c|}{ Quantity growth rate $(\%)$} & \multicolumn{3}{|c|}{ Price growth rate $(\%)$} \\
\hline & & $\begin{array}{c}1990-91 \text { to } \\
2000-01\end{array}$ & $\begin{array}{c}2001-02 \text { to } \\
2015-16\end{array}$ & $\begin{array}{c}1990-91 \text { to } \\
2015-16\end{array}$ & $\begin{array}{c}1990-91 \text { to } \\
2000-01\end{array}$ & $\begin{array}{c}2001-02 \text { to } \\
2015-16\end{array}$ & $\begin{array}{c}1990-91 \text { to } \\
2015-16 \\
\end{array}$ \\
\hline \multirow{2}{*}{$\begin{array}{c}\text { Groun } \\
\text { dnut }\end{array}$} & $\begin{array}{c}\text { Expo } \\
\mathrm{rt}\end{array}$ & $\begin{array}{c}15.90 \\
(125.12) \\
\end{array}$ & $\begin{array}{c}11.04 \\
(161.97) \\
\end{array}$ & $\begin{array}{c}12.23 \\
(116.91) \\
\end{array}$ & $\begin{array}{c}2.77 \\
(372.09) \\
\end{array}$ & $\begin{array}{c}6.19 \\
(319.98) \\
\end{array}$ & $\begin{array}{c}4.41 \\
(259.20) \\
\end{array}$ \\
\hline & $\begin{array}{c}\text { Impo } \\
\mathrm{rt}\end{array}$ & $\begin{array}{c}-5.76 \\
(78.73) \\
\end{array}$ & $\begin{array}{c}20.41 \\
(70.19)\end{array}$ & $\begin{array}{c}2.05 \\
(52.04)\end{array}$ & $\begin{array}{c}0.00 \\
(31.62)\end{array}$ & $\begin{array}{c}0.00 \\
(79.62)\end{array}$ & $\begin{array}{c}0.00 \\
(56.04)\end{array}$ \\
\hline \multirow{2}{*}{$\begin{array}{l}\text { Soybe } \\
\text { an }\end{array}$} & $\begin{array}{c}\text { Expo } \\
\mathrm{rt}\end{array}$ & $\begin{array}{c}63.03 \\
(43.92) \\
\end{array}$ & $\begin{array}{c}42.57 \\
(77.72) \\
\end{array}$ & $\begin{array}{c}27.34 \\
(63.17) \\
\end{array}$ & $\begin{array}{c}-2.87 \\
(67.52) \\
\end{array}$ & $\begin{array}{c}-3.76 \\
(208.22) \\
\end{array}$ & $\begin{array}{c}3.36 \\
(123.78) \\
\end{array}$ \\
\hline & $\begin{array}{c}\text { Impo } \\
\text { rt }\end{array}$ & $\begin{array}{l}-66.88 \\
(38.23) \\
\end{array}$ & $\begin{array}{l}134.30 \\
(41.84) \\
\end{array}$ & $\begin{array}{c}-1.66 \\
(39.67) \\
\end{array}$ & $\begin{array}{c}0.00 \\
(39.40) \\
\end{array}$ & $\begin{array}{c}-12.52 \\
(101.02) \\
\end{array}$ & $\begin{array}{c}4.19 \\
(58.69) \\
\end{array}$ \\
\hline \multirow{2}{*}{$\begin{array}{l}\text { Niger } \\
\text { seeds }\end{array}$} & $\begin{array}{c}\text { Expo } \\
\mathrm{rt}\end{array}$ & $\begin{array}{c}10.99 \\
(236.04) \\
\end{array}$ & $\begin{array}{c}-2.98 \\
(266.68) \\
\end{array}$ & $\begin{array}{c}1.59 \\
(232.97) \\
\end{array}$ & $\begin{array}{c}-0.94 \\
(848.08) \\
\end{array}$ & $\begin{array}{c}7.50 \\
(288.62) \\
\end{array}$ & $\begin{array}{c}2.72 \\
(320.00) \\
\end{array}$ \\
\hline & $\begin{array}{c}\text { Impo } \\
\mathrm{rt}\end{array}$ & $\begin{array}{c}0.00 \\
(0.00) \\
\end{array}$ & $\begin{array}{c}0.00 \\
(0.00) \\
\end{array}$ & $\begin{array}{c}20.24 \\
(68.89) \\
\end{array}$ & $\begin{array}{c}0.00 \\
(0.00)\end{array}$ & $\begin{array}{c}0.00 \\
(0.00)\end{array}$ & $\begin{array}{c}0.00 \\
(79.94)\end{array}$ \\
\hline \multirow{2}{*}{$\begin{array}{l}\text { Musta } \\
\text { rd }\end{array}$} & $\begin{array}{c}\text { Expo } \\
\text { rt }\end{array}$ & $\begin{array}{c}58.86 \\
(61.76) \\
\end{array}$ & $\begin{array}{c}3.63 \\
(187.86) \\
\end{array}$ & $\begin{array}{c}24.35 \\
(99.90) \\
\end{array}$ & $\begin{array}{c}-3.63 \\
(476.88) \\
\end{array}$ & $\begin{array}{c}3.14 \\
(556.73) \\
\end{array}$ & $\begin{array}{c}0.12 \\
(475.79) \\
\end{array}$ \\
\hline & $\begin{array}{c}\text { Impo } \\
\mathrm{rt}\end{array}$ & $\begin{array}{c}33.66 \\
(149.87) \\
\end{array}$ & $\begin{array}{c}-5.77 \\
(99.50) \\
\end{array}$ & $\begin{array}{c}11.05 \\
(122.28) \\
\end{array}$ & $\begin{array}{c}33.66 \\
(104.17) \\
\end{array}$ & $\begin{array}{c}-5.77 \\
(220.68) \\
\end{array}$ & $\begin{array}{c}11.05 \\
(118.46) \\
\end{array}$ \\
\hline \multirow{2}{*}{$\begin{array}{l}\text { Safflo } \\
\text { wer }\end{array}$} & $\begin{array}{c}\text { Expo } \\
\text { rt }\end{array}$ & $\begin{array}{c}-1.69 \\
(102.55) \\
\end{array}$ & $\begin{array}{c}2.24 \\
(605.95) \\
\end{array}$ & $\begin{array}{c}11.94 \\
(153.41) \\
\end{array}$ & $\begin{array}{c}1.72 \\
(522.05) \\
\end{array}$ & $\begin{array}{c}1.33 \\
(122.79) \\
\end{array}$ & $\begin{array}{c}1.31 \\
(170.42) \\
\end{array}$ \\
\hline & $\begin{array}{c}\text { Impo } \\
\mathrm{rt}\end{array}$ & $\begin{array}{c}0.00 \\
(0.00) \\
\end{array}$ & $\begin{array}{c}0.00 \\
(0.00) \\
\end{array}$ & $\begin{array}{c}25.26 \\
(63.65) \\
\end{array}$ & $\begin{array}{c}0.00 \\
(0.00) \\
\end{array}$ & $\begin{array}{c}0.00 \\
(0.00) \\
\end{array}$ & $\begin{array}{c}0.00 \\
(26.73) \\
\end{array}$ \\
\hline \multirow{2}{*}{$\begin{array}{c}\text { Sesam } \\
\text { um }\end{array}$} & $\begin{array}{c}\text { Expo } \\
\text { rt }\end{array}$ & $\begin{array}{c}20.83 \\
(165.01) \\
\end{array}$ & $\begin{array}{c}2.74 \\
(301.91) \\
\end{array}$ & $\begin{array}{c}10.79 \\
(156.38)\end{array}$ & $\begin{array}{c}-2.70 \\
(625.95) \\
\end{array}$ & $\begin{array}{c}6.58 \\
(250.03) \\
\end{array}$ & $\begin{array}{c}2.01 \\
(218.10)\end{array}$ \\
\hline & $\begin{array}{c}\text { Impo } \\
\text { rt }\end{array}$ & $\begin{array}{l}-10.46 \\
(93.49) \\
\end{array}$ & $\begin{array}{c}81.45 \\
(72.17) \\
\end{array}$ & $\begin{array}{c}21.22 \\
(53.65) \\
\end{array}$ & $\begin{array}{c}0.00 \\
(69.92) \\
\end{array}$ & $\begin{array}{c}0.00 \\
(264.14) \\
\end{array}$ & $\begin{array}{c}2.37 \\
(122.06) \\
\end{array}$ \\
\hline \multirow{2}{*}{$\begin{array}{l}\text { Sunflo } \\
\text { wer }\end{array}$} & $\begin{array}{c}\text { Expo } \\
\mathrm{rt}\end{array}$ & $\begin{array}{c}-3.87 \\
(174.22) \\
\end{array}$ & $\begin{array}{c}9.31 \\
(220.19) \\
\end{array}$ & $\begin{array}{c}3.51 \\
(150.57) \\
\end{array}$ & $\begin{array}{c}20.42 \\
(157.68) \\
\end{array}$ & $\begin{array}{c}1.84 \\
(373.38) \\
\end{array}$ & $\begin{array}{c}7.85 \\
(227.66) \\
\end{array}$ \\
\hline & $\begin{array}{c}\text { Impo } \\
\mathrm{rt}\end{array}$ & $\begin{array}{c}-100.00 \\
(35.25)\end{array}$ & $\begin{array}{c}0.00 \\
(66.48)\end{array}$ & $\begin{array}{c}28.90 \\
(50.85)\end{array}$ & $\begin{array}{c}0.00 \\
(30.15)\end{array}$ & $\begin{array}{c}0.00 \\
(53.71)\end{array}$ & $\begin{array}{c}0.00 \\
(43.65)\end{array}$ \\
\hline
\end{tabular}

Source: CMIE Commodities, accessed on $3^{\text {rd }}$ June 2017, Parenthesis in the bracket indicates $\mathrm{CV}(\%)$ 


\section{Export Import Prices Elasticities of India's Oilseed crops}

How responsive are export \& Import quantities to a change in international prices is of direct relevance in international economics. Trade price elasticities are signals for exporters or importers to increase or decrease their trade as it indicates exports or imports responsiveness to changes in price.

Export import prices elasticities of India's oilseeds crops were presented in Tables 3. During the period 1990-91 to 2015-16, the export import price elasticities of all oilseeds were found to be positive except imports price elasticity of soybean $(-0.45 \%)$ crop. The exports price elasticity of soybean $(0.42 \%)$, mustard $(0.97 \%)$, safflower $(0.72 \%)$, sesamum $(0.58 \%)$ and sunflower $(0.09 \%)$ were found to be marginally higher than compared to imports.

The study found that the exports price elasticity of soybean, mustard, safflower, sesamum and sunflower were found to be marginally higher than compared to imports.

Table 3. Export-Import Prices elasticities of Oilseed crops (1990-2016)

\begin{tabular}{|c|c|c|c|c|}
\hline \multirow{2}{*}{ Crops } & \multirow{2}{*}{ Variables } & \multicolumn{3}{|c|}{ Export Import price elasticity (\%) } \\
\hline & & $1990-91$ to $2000-01$ & $2001-02$ to $2015-16$ & $1990-91$ to $2015-16$ \\
\hline \multirow{2}{*}{ Groundnut } & Export & 0.70 & 0.35 & 0.31 \\
\hline & Import & 0.72 & 0.00 & 1.00 \\
\hline \multirow{2}{*}{ Soybean } & Export & 1.38 & 1.78 & 0.42 \\
\hline & Import & 1.00 & 3.83 & -0.45 \\
\hline \multirow{2}{*}{ Niger seeds } & Export & 1.17 & -0.41 & 0.25 \\
\hline & Import & 0.00 & 0.00 & 0.67 \\
\hline \multirow{2}{*}{ Mustard } & Export & 1.45 & 0.43 & 0.97 \\
\hline & Import & 0.00 & 2.93 & 0.00 \\
\hline \multirow{2}{*}{ Safflower } & Export & 0.00 & 0.57 & 0.72 \\
\hline & Import & 0.00 & 0.00 & 0.00 \\
\hline \multirow{2}{*}{ Sesamum } & Export & 1.42 & 0.17 & 0.58 \\
\hline & Import & 0.70 & 0.00 & 0.54 \\
\hline \multirow{2}{*}{ Sunflower } & Export & -0.09 & 0.70 & 0.09 \\
\hline & Import & 0.00 & 0.00 & 0.00 \\
\hline
\end{tabular}

Source: CMIE Commodities, Accessed on $3^{\text {rd }}$ June 2017.

\section{Export Import Prices Trends of Oilseeds crops}

Three Year Moving Average (3MA) Method was employed to find out the trends of the exports imports price of oilseeds crops. The exports price and imports price trends of oilseeds were presented in Figures 1 and 2. The export price of groundnut, niger seeds, mustard and sunflower more or less witnessed stable trend. The sesamum export price has witnessed more or less stable trends up to 2006-07, But 2007-08 onwards sesamum exports 
price trend were found increasing with fluctuations. The imports price of sesamum has witnessed increasing trend with fluctuations and in remaining oilseeds crops imports price has witnessed mixed trends.

The study found that the export price trends of groundnut, niger seeds, mustard and sunflower were found to be more or less stable up to 2005-06, But 2006-07 onwards these crops exports price trend were found increasing with fluctuations. The imports price of sesamum has witnessed increasing trend with fluctuations and in remaining oilseeds crops imports price was witnessed mixed trends.

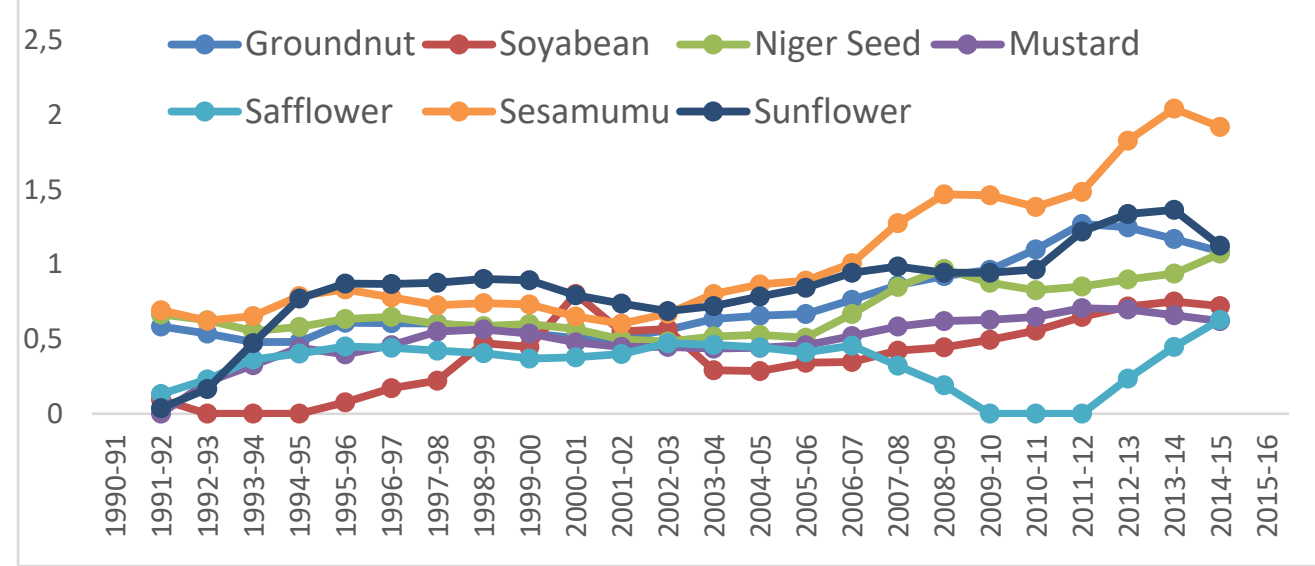

Fig 1: Export price (US\$/Kg) trends of oilseeds crops

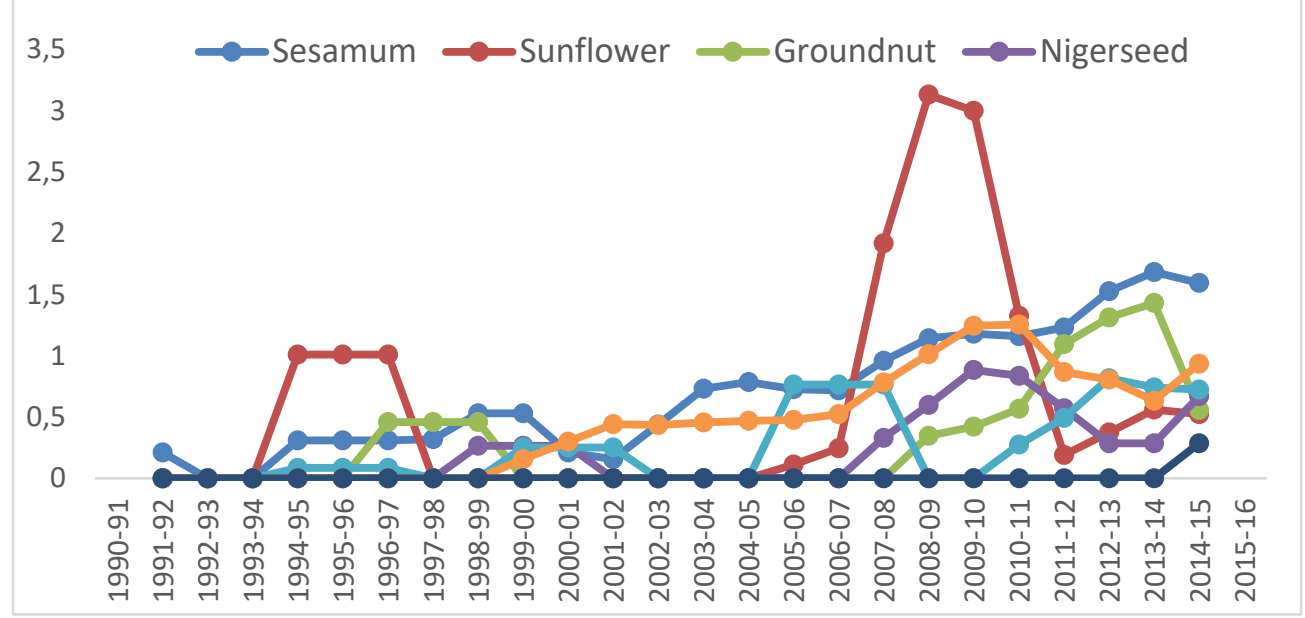

Fig 2: Import price (US\$/Kg) trends of oilseeds crops

\section{Growth Rate and Price Elasticity of Top 10 Destinations of Oilseeds crops}

Top 10 India's exports imports destinations and their share in the world exports imports of oilseeds crops, groundnut, soybean, sesamum, sunflower and niger seeds were presented in Table 4, 5, 6, 7 and 8 
respectively. India exports and imports these commodities to ranges from 40 to 130 countries of the world. For each commodity, the countries classified in to the top 10 export countries which accounted major share of exports and rest as other countries.

During the period 1990-91 to 2015-16, the major India's exports destinations for groundnut (Table 4) are Indonesia (37.54\%) Malaysia (12.53\%) Vietnam (9.49\%); for soybean (Table 5) are USA (32.77\%), Canada (13.76\%) and Vietnam (6.94 \%); for sesamum (Table 6) are South Korea (8.68\%), Vietnam (7.50\%) and USA $(6.90 \%)$; for sunflower (Table 7) are Philippines (21.41\%), UK (17.30\%) and Netherlands (15.23\%); for niger seeds (Table 8) are USA (79.30\%), Belgium (3.33\%) and UK $(2.50 \%)$.

During the period $1990-91$ to $2015-16$, the major India's import destinations for groundnut (Table 4) are Germany (6.84\%), Nepal (5.64\%) and China (4.39\%); for soybean (Table 5) are USA (53.22\%), Ukraine $(2.86 \%)$ and UAE (0.75 \%); for sesamum (Table 6) are Nigeria (16.08\%), Pakistan (11.33\%) and UAE (1.98\%); for sunflower (Table 7) are Ukraine (56.21\%), Tanzania (23.54\%) and Russia (9.74\%).

The study found that during the period 1990-91 to 2015-2016, major India's exports destinations are for groundnut, soybean, niger seeds, sesamum, and sunflower are Indonesia, USA, South Korea and Philippines respectively. The major India's imports destinations are Germany, USA, Nigeria and Ukraine for groundnut, soybean, sesamum, and sunflower respectively.

Table 4. Top 10 India's Exports Imports Destinations of Groundnut (1990-2016)

\begin{tabular}{|c|c|c|c|c|c|c|}
\hline Country & $\begin{array}{c}\text { Total } \\
\text { Qty } \\
\text { Tonne } \\
\text { s })\end{array}$ & $\begin{array}{c}\text { \% of Qty to } \\
\text { World Total }\end{array}$ & $\begin{array}{c}\text { Total } \\
\text { Value }\end{array}$ & $\begin{array}{c}\text { \% of Total } \\
\text { Value }\end{array}$ & $\begin{array}{c}\text { Average price } \\
\text { (US\$/Kg) }\end{array}$ & $\begin{array}{c}\text { \% of } \\
\text { Average } \\
\text { Price }\end{array}$ \\
\hline \multicolumn{7}{|c|}{ Top 10 India's Exports Destinations of Groundnut } \\
\hline $\begin{array}{c}\text { Indonesi } \\
\text { a }\end{array}$ & $\begin{array}{c}249058 \\
3.25\end{array}$ & 37.54 & 2292.20 & 36.44 & 0.71 & 11.29 \\
\hline Malaysia & $\begin{array}{c}831558 . \\
31\end{array}$ & 12.53 & 797.30 & 12.68 & 0.73 & 11.59 \\
\hline Vietnam & $\begin{array}{c}629506 . \\
87\end{array}$ & 9.49 & 780.20 & 12.40 & 0.51 & 8.10 \\
\hline $\begin{array}{c}\text { Philippin } \\
\text { es }\end{array}$ & $\begin{array}{c}609103 . \\
25\end{array}$ & 9.18 & 624.90 & 9.93 & 0.72 & 11.54 \\
\hline UK & $\begin{array}{c}247935 . \\
85\end{array}$ & 3.74 & 165.00 & 2.62 & 0.65 & 10.37 \\
\hline Thailand & $\begin{array}{c}210448 . \\
11\end{array}$ & 3.17 & 248.40 & 3.95 & 0.48 & 7.63 \\
\hline $\begin{array}{c}\text { Netherla } \\
\text { nds }\end{array}$ & $\begin{array}{c}208666 . \\
20\end{array}$ & 3.15 & 53.60 & 0.85 & 0.83 & 13.29 \\
\hline Pakistan & $\begin{array}{c}157985 \\
16\end{array}$ & 2.38 & 137.10 & 2.18 & 0.38 & 6.07 \\
\hline
\end{tabular}




\begin{tabular}{|c|c|c|c|c|c|c|}
\hline China & $\begin{array}{c}132844 . \\
35\end{array}$ & 2.00 & 146.40 & 2.33 & 0.52 & 8.34 \\
\hline Ukraine & $\begin{array}{c}121446 . \\
77\end{array}$ & 1.83 & 131.90 & 2.10 & 0.74 & 11.79 \\
\hline $\begin{array}{c}\text { Other } \\
\text { country }\end{array}$ & $\begin{array}{c}993883 \\
58\end{array}$ & 14.98 & 913.30 & 14.52 & - & - \\
\hline World & $\begin{array}{c}663396 \\
1.69\end{array}$ & 100.00 & 6290.30 & 100.00 & 6.28 & 100.00 \\
\hline \multicolumn{7}{|c|}{ Top 10 India's Imports Destinations of Groundnut } \\
\hline Germany & 259.00 & 6.84 & 0.00 & 0.00 & 0.00 & 0.00 \\
\hline Nepal & 213.63 & 5.64 & 0.10 & 5.88 & 0.05 & 33.70 \\
\hline China & 166.43 & 4.39 & 0.10 & 5.88 & 0.06 & 37.67 \\
\hline UAE & 125.20 & 3.30 & 0.10 & 5.88 & 0.04 & 28.63 \\
\hline USA & 38.00 & 1.00 & 0.00 & 0.00 & 0.00 & 0.00 \\
\hline Japan & 37.00 & 0.98 & 0.00 & 0.00 & 0.00 & 0.00 \\
\hline $\begin{array}{c}\text { UK } \\
\text { Ualaysia }\end{array}$ & 27.00 & 0.98 & 0.00 & 0.00 & 0.00 & 0.00 \\
\hline Malo & 0.53 & 0.00 & 0.00 & 0.00 & 0.00 \\
\hline Russia & 20.00 & 0.53 & 0.00 & 0.00 & 0.00 & 0.00 \\
\hline $\begin{array}{c}\text { Singapor } \\
\text { e }\end{array}$ & 19.00 & 0.50 & 0.00 & 0.00 & 0.00 & 0.00 \\
\hline $\begin{array}{c}\text { other } \\
\text { country }\end{array}$ & 2854.00 & 75.32 & 1.40 & 82.35 & - & - \\
\hline world & 3789.26 & 100.00 & 1.70 & 100.00 & 0.15 & 100.00 \\
\hline
\end{tabular}

Source: CMIE Commodities, Accessed on $3^{\text {rd }}$ June 2017 (Qty in Tonnes, Value in US\$ Million)

Table 5. Top 10 India's Exports Imports Destinations of Soybean (1990-2016)

\begin{tabular}{|c|c|c|c|c|c|c|}
\hline Country & $\begin{array}{c}\text { Total } \\
\text { Qty } \\
\text { (Tonnes } \\
\text { ) }\end{array}$ & $\begin{array}{c}\text { \% of Qty to } \\
\text { World Total }\end{array}$ & $\begin{array}{c}\text { Total } \\
\text { Value }\end{array}$ & $\begin{array}{c}\text { \% of Total } \\
\text { Value }\end{array}$ & $\begin{array}{c}\text { Average price } \\
\text { (US\$/Kg) }\end{array}$ & $\begin{array}{c}\text { \% of Average } \\
\text { Price }\end{array}$ \\
\hline \multicolumn{7}{|c|}{ Top 10 India's Exports Destinations of Soybean } \\
\hline USA & $\begin{array}{c}365714 . \\
57\end{array}$ & 32.77 & 260.90 & 42.26 & 0.25 & 31.25 \\
\hline Canada & $\begin{array}{c}153542 . \\
04\end{array}$ & 13.76 & 106.90 & 17.32 & 0.18 & 22.48 \\
\hline Vietnam & $\begin{array}{c}77451.1 \\
2\end{array}$ & 6.94 & 21.90 & 3.55 & 0.00 & 0.00 \\
\hline Iran & $\begin{array}{c}65107.0 \\
6\end{array}$ & 5.83 & 18.20 & 2.95 & 0.00 & 0.00 \\
\hline Indonesia & $\begin{array}{c}58369.9 \\
3\end{array}$ & 5.23 & 14.80 & 2.40 & 0.00 & 0.00 \\
\hline Pakistan & $\begin{array}{c}45821.3 \\
0\end{array}$ & 4.11 & 11.80 & 1.91 & 0.07 & 8.78 \\
\hline $\begin{array}{c}\text { South } \\
\text { Korea }\end{array}$ & $\begin{array}{c}40874.2 \\
4\end{array}$ & 3.66 & 18.40 & 2.98 & 0.00 & 0.00 \\
\hline France & $\begin{array}{c}37213.6 \\
8\end{array}$ & 3.33 & 27.40 & 4.44 & 0.16 & 19.52 \\
\hline
\end{tabular}




\begin{tabular}{|c|c|c|c|c|c|c|}
\hline Belgium & $\begin{array}{c}24289.7 \\
7\end{array}$ & 2.18 & 18.50 & 3.00 & 0.14 & 17.97 \\
\hline Russia & $\begin{array}{c}19693.4 \\
3 \\
\end{array}$ & 1.76 & 4.30 & 0.70 & 0.00 & 0.00 \\
\hline $\begin{array}{c}\text { Other } \\
\text { country }\end{array}$ & $\begin{array}{c}227904 . \\
69\end{array}$ & 20.42 & 114.20 & 18.50 & - & - \\
\hline World & $\begin{array}{c}111598 \\
1.81 \\
\end{array}$ & 100.00 & 617.30 & 100.00 & 0.80 & 100.00 \\
\hline \multicolumn{7}{|c|}{ Top 10 India's Imports Destinations of Soybean } \\
\hline USA & $\begin{array}{c}31209.2 \\
9\end{array}$ & 53.22 & 8.20 & 64.06 & 0.13 & 13.37 \\
\hline Ukraine & 1679.00 & 2.86 & 0.00 & 0.00 & 0.02 & 2.39 \\
\hline UAE & 441.00 & 0.75 & 0.50 & 3.91 & 0.05 & 5.70 \\
\hline Canada & 239.00 & 0.41 & 0.00 & 0.00 & 0.56 & 58.98 \\
\hline China & 125.09 & 0.21 & 0.10 & 0.78 & 0.04 & 4.14 \\
\hline Japan & 34.44 & 0.06 & 0.00 & 0.00 & 0.00 & 0.00 \\
\hline Israel & 32.50 & 0.06 & 0.20 & 1.56 & 0.15 & 15.42 \\
\hline Nepal & 19.37 & 0.03 & 0.00 & 0.00 & 0.00 & 0.00 \\
\hline Indonesia & 10.00 & 0.02 & 0.00 & 0.00 & 0.00 & 0.00 \\
\hline $\begin{array}{c}\text { Singapor } \\
\mathrm{e}\end{array}$ & 8.01 & 0.01 & 0.00 & 0.00 & 0.00 & 0.00 \\
\hline $\begin{array}{c}\text { other } \\
\text { country }\end{array}$ & $\begin{array}{c}24844.0 \\
7 \\
\end{array}$ & 42.37 & 3.80 & 29.69 & - & - \\
\hline world & $\begin{array}{c}58641.7 \\
6 \\
\end{array}$ & 100.00 & 12.80 & 100.00 & 0.95 & 100.00 \\
\hline
\end{tabular}

Source: CMIE Commodities, Accessed on $3^{\text {rd }}$ June 2017 (Qty in Tonnes, Value in US\$

Million)

Table 6. Top 10 India's Exports Imports Destinations of Sesamum (1990-2016)

\begin{tabular}{|c|c|c|c|c|c|c|}
\hline Country & $\begin{array}{c}\text { Total } \\
\text { Qty } \\
\text { Tonne } \\
\text { s) }\end{array}$ & $\begin{array}{c}\text { \% of Qty to } \\
\text { World Total }\end{array}$ & $\begin{array}{c}\text { Total } \\
\text { Value }\end{array}$ & $\begin{array}{c}\text { \% of Total } \\
\text { Value }\end{array}$ & $\begin{array}{c}\text { Average price } \\
\text { (US\$/Kg) }\end{array}$ & $\begin{array}{c}\text { \% of } \\
\text { Average } \\
\text { Price }\end{array}$ \\
\hline \multicolumn{7}{|c|}{ Top 10 India's Exports Destinations } \\
\hline $\begin{array}{c}\text { South } \\
\text { Korea }\end{array}$ & $\begin{array}{c}410262 . \\
44\end{array}$ & 8.64 & 596.00 & 10.03 & 0.89 & 9.19 \\
\hline Vietnam & $\begin{array}{c}355973 \\
52\end{array}$ & 7.50 & 508.80 & 8.56 & 0.54 & 5.63 \\
\hline USA & $\begin{array}{c}329387 \\
46\end{array}$ & 6.94 & 454.50 & 7.64 & 1.19 & 12.27 \\
\hline Taiwan & $\begin{array}{c}321151 . \\
49\end{array}$ & 6.77 & 306.30 & 5.15 & 0.82 & 8.48 \\
\hline $\begin{array}{c}\text { Netherla } \\
\text { nds }\end{array}$ & $\begin{array}{c}282401 . \\
17\end{array}$ & 5.95 & 292.00 & 4.91 & 1.10 & 11.43 \\
\hline Turkey & $\begin{array}{c}278877 . \\
01\end{array}$ & 5.88 & 289.10 & 4.86 & 1.01 & 10.41 \\
\hline China & $\begin{array}{c}261313 \\
11\end{array}$ & 5.51 & 279.50 & 4.70 & 0.79 & 8.14 \\
\hline Egypt & $\begin{array}{c}219610 . \\
33\end{array}$ & 4.63 & 198.00 & 3.33 & 0.94 & 9.76 \\
\hline
\end{tabular}




\begin{tabular}{|c|c|c|c|c|c|c|}
\hline Germany & $\begin{array}{c}210696 . \\
81\end{array}$ & 4.44 & 289.10 & 4.86 & 1.22 & 12.65 \\
\hline Greece & $\begin{array}{c}197510 . \\
50\end{array}$ & 4.16 & 261.80 & 4.40 & 1.16 & 12.04 \\
\hline $\begin{array}{c}\text { Other } \\
\text { country }\end{array}$ & $\begin{array}{c}187878 \\
5.25\end{array}$ & 39.59 & 2470.00 & 41.55 & & 0.00 \\
\hline World & $\begin{array}{c}474596 \\
9.07 \\
\end{array}$ & 100.00 & 5945.10 & 100.00 & 9.66 & 100.00 \\
\hline \multicolumn{7}{|c|}{ Top 10 India's Imports Destinations } \\
\hline Nigeria & $\begin{array}{c}35624.5 \\
4 \\
\end{array}$ & 16.08 & 48.40 & 15.13 & 0.41 & 22.72 \\
\hline Pakistan & $\begin{array}{c}25097.8 \\
4\end{array}$ & 11.33 & 42.70 & 13.35 & 0.57 & 31.54 \\
\hline UAE & 4387.01 & 1.98 & 5.00 & 1.56 & 0.29 & 16.00 \\
\hline $\begin{array}{l}\text { South } \\
\text { Korea } \\
\end{array}$ & 1236.00 & 0.56 & 1.60 & 0.50 & 0.10 & 5.47 \\
\hline Germany & 732.78 & 0.33 & 0.40 & 0.13 & 0.03 & 1.78 \\
\hline Taiwan & 595.23 & 0.27 & 0.30 & 0.09 & 0.03 & 1.65 \\
\hline $\begin{array}{c}\text { Singapor } \\
\mathrm{e}\end{array}$ & 564.00 & 0.25 & 0.70 & 0.22 & 0.22 & 12.04 \\
\hline Brazil & 552.00 & 0.25 & 0.30 & 0.09 & 0.04 & 2.30 \\
\hline Russia & 397.50 & 0.18 & 0.40 & 0.13 & 0.12 & 6.52 \\
\hline Nepal & 317.06 & 0.14 & 0.00 & 0.00 & 0.00 & 0.00 \\
\hline $\begin{array}{c}\text { Other } \\
\text { country }\end{array}$ & $\begin{array}{c}152036 . \\
90 \\
\end{array}$ & 68.63 & 220.10 & 68.80 & & 0.00 \\
\hline World & $\begin{array}{c}221540 . \\
84\end{array}$ & 100.00 & 319.90 & 100.00 & 1.82 & 100.00 \\
\hline
\end{tabular}

Source: CMIE Commodities, Accessed on $3^{\text {rd }}$ June 2017 (Qty in Tonnes, Value in US\$ Million)

Table 7. Top 10 India's Exports Destinations of Sunflower (1990-2016)

\begin{tabular}{|c|c|c|c|c|c|c|}
\hline Country & $\begin{array}{c}\text { Qty } \\
\text { (Tonnes } \\
\text { ) }\end{array}$ & $\begin{array}{c}\text { \% of Qty to } \\
\text { World Total }\end{array}$ & $\begin{array}{c}\text { Total } \\
\text { Value }\end{array}$ & $\begin{array}{c}\text { \% of Total } \\
\text { Value }\end{array}$ & $\begin{array}{c}\text { Average price } \\
\text { (US } \$ / K g)\end{array}$ & $\begin{array}{c}\text { \% of } \\
\text { Average } \\
\text { Price }\end{array}$ \\
\hline $\begin{array}{c}\text { Philippin } \\
\text { es }\end{array}$ & $\begin{array}{c}13772.3 \\
3\end{array}$ & 21.41 & 9.00 & 14.20 & 0.31 & 3.85 \\
\hline UK & $\begin{array}{c}11129.3 \\
6\end{array}$ & 17.30 & 11.50 & 18.14 & 0.56 & 6.99 \\
\hline $\begin{array}{c}\text { Netherla } \\
\text { nds }\end{array}$ & 9800.16 & 15.23 & 8.60 & 13.56 & 4.25 & 53.07 \\
\hline Pakistan & 4410.50 & 6.86 & 12.90 & 20.35 & 1.37 & 17.14 \\
\hline Germany & 3683.70 & 5.73 & 2.80 & 4.42 & 0.33 & 4.11 \\
\hline Belgium & 3531.11 & 5.49 & 2.60 & 4.10 & 0.25 & 3.07 \\
\hline USA & 2394.36 & 3.72 & 2.10 & 3.31 & 0.30 & 3.79 \\
\hline Australia & 2323.21 & 3.61 & 1.50 & 2.37 & 0.20 & 2.56 \\
\hline Nepal & 1435.33 & 2.23 & 1.20 & 1.89 & 0.16 & 1.98 \\
\hline
\end{tabular}




\begin{tabular}{|c|c|c|c|c|c|c|}
\hline Taiwan & 1088.62 & 1.69 & 0.80 & 1.26 & 0.27 & 3.43 \\
\hline $\begin{array}{l}\text { Other } \\
\text { country }\end{array}$ & $\begin{array}{c}10769.0 \\
2 \\
\end{array}$ & 16.74 & 10.40 & 16.40 & 0.00 & 0.00 \\
\hline World & $\begin{array}{c}64337.6 \\
9 \\
\end{array}$ & 100.00 & 63.40 & 100.00 & 8.00 & 100.00 \\
\hline \multicolumn{7}{|c|}{ Top 10 India's Imports Destinations } \\
\hline Ukraine & $\begin{array}{c}6991 . \\
50 \\
\end{array}$ & 56.21 & 1.90 & 20.88 & 0.04 & 2.07 \\
\hline Tanzania & $\begin{array}{c}2928 . \\
11\end{array}$ & 23.54 & 1.30 & 14.29 & 0.04 & 2.51 \\
\hline Russia & $\begin{array}{c}1211 . \\
98\end{array}$ & 9.74 & 1.50 & 16.48 & 0.31 & 17.41 \\
\hline USA & $\begin{array}{c}450.5 \\
2\end{array}$ & 3.62 & 1.60 & 17.58 & 0.16 & 9.06 \\
\hline Australia & $\begin{array}{c}418.6 \\
6 \\
\end{array}$ & 3.37 & 1.20 & 13.19 & 0.86 & 48.51 \\
\hline France & $\begin{array}{c}181.6 \\
2 \\
\end{array}$ & 1.46 & 0.90 & 9.89 & 0.24 & 13.58 \\
\hline $\begin{array}{l}\text { South } \\
\text { Africa }\end{array}$ & 54.00 & 0.43 & 0.10 & 1.10 & 0.12 & 6.87 \\
\hline China & 52.13 & 0.42 & 0.00 & 0.00 & 0.00 & 0.00 \\
\hline Egypt & 46.00 & 0.37 & 0.00 & 0.00 & 0.00 & 0.00 \\
\hline Nepal & 45.21 & 0.36 & 0.00 & 0.00 & 0.00 & 0.00 \\
\hline $\begin{array}{c}\text { other } \\
\text { country }\end{array}$ & 59.43 & 0.48 & 0.60 & 6.59 & & 0.00 \\
\hline world & \begin{tabular}{|c|}
12439 \\
.16 \\
\end{tabular} & 100.00 & 9.10 & 100.00 & 1.77 & 100.00 \\
\hline
\end{tabular}

Source: CMIE Commodities, Accessed on $3^{\text {rd }}$ June 2017 (Qty in Tonnes, Value in US\$ Million)

Table 8. Top 10 India's Exports Destinations of Niger seeds (1990-2016)

\begin{tabular}{|c|c|c|c|c|c|c|}
\hline Country & $\begin{array}{c}\text { Total } \\
\text { Qty } \\
\text { (Tonne } \\
\text { s) }\end{array}$ & $\begin{array}{l}\% \text { of Qty to } \\
\text { World Total }\end{array}$ & $\begin{array}{l}\text { Total } \\
\text { Value }\end{array}$ & $\begin{array}{l}\% \text { of Total } \\
\text { Value }\end{array}$ & $\begin{array}{l}\text { Average price } \\
\text { (US } \$ / \mathrm{Kg})\end{array}$ & $\begin{array}{c}\% \text { of } \\
\text { Average } \\
\text { Price }\end{array}$ \\
\hline USA & $\begin{array}{c}37376 \\
9.84\end{array}$ & 79.30 & 251.10 & 77.76 & 0.71 & 15.05 \\
\hline Belgium & $\begin{array}{c}15696 . \\
70\end{array}$ & 3.33 & 11.10 & 3.44 & 0.63 & 13.45 \\
\hline UK & $\begin{array}{c}11803 . \\
05\end{array}$ & 2.50 & 9.50 & 2.94 & 0.47 & 9.99 \\
\hline Italy & $\begin{array}{c}10744 . \\
13\end{array}$ & 2.28 & 6.50 & 2.01 & 0.64 & 13.57 \\
\hline $\begin{array}{c}\text { Singapor } \\
\mathrm{e}\end{array}$ & $\begin{array}{c}10738 . \\
38\end{array}$ & 2.28 & 6.30 & 1.95 & 0.00 & 0.00 \\
\hline Mexico & $\begin{array}{c}7876.1 \\
1\end{array}$ & 1.67 & 5.50 & 1.70 & 0.54 & 11.46 \\
\hline $\begin{array}{l}\text { Netherla } \\
\text { nds }\end{array}$ & $\begin{array}{c}6817.2 \\
0 \\
\end{array}$ & 1.45 & 4.20 & 1.30 & 0.51 & 10.87 \\
\hline Spain & 6641.2 & 1.41 & 5.00 & 1.55 & 0.70 & 14.90 \\
\hline
\end{tabular}




\begin{tabular}{|c|c|c|c|c|c|c|}
\hline & 7 & & & & & \\
\hline Canada & $\begin{array}{c}5395.3 \\
2\end{array}$ & 1.14 & 4.50 & 1.39 & 0.50 & 10.70 \\
\hline Brazil & $\begin{array}{c}3351.5 \\
1\end{array}$ & 0.71 & 3.00 & 0.93 & 0.00 & 0.00 \\
\hline $\begin{array}{c}\text { Other } \\
\text { country }\end{array}$ & $\begin{array}{c}18499 \\
92\end{array}$ & 3.93 & 16.20 & 5.02 & 0.00 & 0.00 \\
\hline World & $\begin{array}{c}47133 \\
\text { 3.42 }\end{array}$ & 100.00 & 322.90 & 100.00 & 4.70 & 100.00 \\
\hline
\end{tabular}

Source: CMIE Commodities, Accessed on $3^{\text {rd }}$ June 2017 (Qty in Tonnes, Value in US\$

Million)

\section{Conclusion}

World price means a price for a good or services in all countries other than one's own. World price influences on international trade. The study found that export prices of oilseeds; groundnut, soybean, niger, safflower, sesamum and sunflower were more than import prices except Mustard. The terms of trade of India's oilseeds were found to be increased for all oilseeds except mustard crop. The exports price growth rate of groundnut, niger seeds, safflower and sunflower were found to be more than imports. Whereas imports price growth rate of crops; soybean, mustard, and sesamum were found to be more than exports. The study found that among oilseeds mustard has high export elasticities $(0.97 \%)$. The study found that the export price trends of groundnut, niger seeds, mustard and sunflower were found to be more or less stable up to 2005-06, but 2006-07 onwards these crops exports price trend were found increasing with fluctuations and the imports price of sesamum has witnessed increasing trend with fluctuations. The study found that export imports prices of oilseeds, groundnut, soybean, safflower, sunflower and niger crops were found to be stable. The study found that during the period 1990-91 to 2015-2016, major India's exports destinations for groundnut, soybean, niger seeds, sesamum, and sunflower are Indonesia, USA, South Korea and Philippines respectively. The major India's imports destinations are Germany, USA, Nigeria and Ukraine for groundnut, soybean, sesamum, and sunflower respectively.

The findings have important implications for policy research and $R \& D$ strategies and response and re-orientation of the R\&D system to the changing trade scenario to benefit from WTO. The study suggests that multilateral trade relationship with high CAGR countries would help in smooth trade of oilseeds. The study findings have important implications to be considered in designing foreign trade agricultural policies and programs to boost trade and foreign earnings of export and import countries. The study could better guide exporters and importers countries for market and price signals of commodities. 
Acknowledgement: A special thanks goes to the SERB, Department of Science Technology. I also thank Ms. Anjani Sneha Vajrala.

\section{References:}

1. Alberto and Stefano (2010), Sovereign default, domestic banks and financial institutions. CEPR Discussion Papers 7955. Available at: https://ideas.repec.org/f/ pma513.html. Accessed on 16-06-2014.

2. Chand, R. and Tewari, S. C. (1991), 'Growth and instability of Indian exports and imports of agricultural commodities', Indian Journal Agricultural Economics, 46(2): 159-165.

3. Chandrashekhar, G. (2013), 'To export value-added products, curbs on oilseeds import must go', Business Line, The Hindu, October 19, 2013. http://www.thehindubusinessline.com/opinion/columns/gchandrashekhar/to-export-valueadded-products-curbs-on-oilseedsimport-must-go/article5251671.ece

4. Chaudhary, M.A. and Qaisrani, A.A. (2002), 'Trade Instability, Investment and Economic Growth in Pakistan', Pakistan Economic and Social Review, Volume 40(1):57-73.

5. CMIE, Centre for monitoring Indian Economy, Accessed on 3rd June, 2017. https://www.cmie.com/.

6. Damodar NG and Sangeetha (2007), 'Basic Econometrics', Tata McGraw Hill Publishing Company Ltd, New Delhi. 2007, pp: 182183.

7. David Hallam (2003), 'Commodity Market Review 2003-2004', UNFAO Commodity and Trade division, 2003, pp:3-18.

8. Encyclopedia (2010), 'World price', The Great Soviet Encyclopedia, 3rd Edition (1970-1979). The Gale Group, Inc. Farmington Hills, USA.

9. Financial Dictionary (2012), 'World price', Ferlex financial dictionary, Ferlex Inc., Huntingdon Valley, USA.

10. Glezakos (1973), 'Export instability and economic growth: a statistical verification', Economic Development and Cultural Change, volume 21:670-678.

11. Government of India (2013), Annual Report 2013-14, Department of Agriculture, Cooperation \& Farmers Welfare, Ministry of Agriculture \& Farmers Welfare, http://agricoop.nic.in/sites/default/files/Annual\%20Report\%20201314.pdf

12. Mahadevaiah, G.S. (2001), 'Export Trade Performance of Indian Cotton- An Econometric Analysis', Ph.D. thesis, University Agricultural Science, Bangalore. 
13. Narayan, P; Chauhan, M S and Chauhan, S (2011). "Oilseeds Scenario in India". Agriculture Today, December, 2011. Pp 40-43. http://agropedia.iitk.ac.in/content/oilseeds-scenario-india

14. Nurkse, R. (1958), 'Quest for a stabilization policy in primary producing countries', Kyklos, volume 2:141-154.

15. Pal, S. (1992), 'Agricultural exports in India: Issues of growth and instability’, Indian Journal Agricultural Economics, 47(2): 185-194.

16. Shweta Saini and Ashok Gulati (2017) "Price Distortions in Indian Agriculture", The World Bank Group report. http://icrier.org/pdf/Price_Distortions_in_Indian_Agriculture_2017.p df

17. Singh, K. and Sangla, K. (2012), 'An Analysis of India's Exports (1991-2006)', ZENITH International Journal of Business Economics \& Management Research, 2(2):79-108. http://zenithresearch.org.in/images/stories/pdf/2012/Feb/ZIJBEMR/7 _ZIJBEMR_VOL2_ISSUE2_FEB2012.pdf.

18. Upender, M. (2007), 'Long run equilibrium between India's exports and imports during 1949-50- 2004-05', Applied Econometrics and International Development. 7:187-196.

19. UNCTAD. United Nations Conference on Trade and Development. 2009. Available at: www.unctad.org/en/PublicationsLibrary/webditctncd2009d1_en.pdf. Accessed on: 24-07-2014.

20. USDA Foreign Agricultural Research Service (2017) "India Oilseeds and Products Annual 2017" GAIN Report Number IN7039. https://gain.fas.usda.gov/Recent\%20GAIN\%20Publications/Oilseeds \%20and\%20Products\%20Annual_New\%20Delhi_India_3-282017.pdf

21. Vijaya Paul Sharma, (2014), 'Problems and Prospects of Oilseeds Production in India', Centre for Management in Agriculture (CMA), Indian Institute of Management (IIM), Ahmedabad, November 2014. https://www.iima.ac.in/c/document_library/get_file?uuid=981f4ee12595-4090-a563-73fc 703e5118\& groupId=62390 